\title{
VITAMIN D LEVEL IN CHILDREN WITH TYPE 1 DIABETES MELLITUS IN DUHOK CITY / KURDISTAN, IRAQ
}

\author{
Azad A. Haleem \\ Department of Paediatric, College of medicine, University of Duhok, Kurdistan Region, Iraq (azad.haleem@uod.ac)
}

Received: Dec. 2018 / Accepted: Feb., 2019 / Published: Mar., 2019

https://doi.org/10.25271/sjuoz.2019.7.1.536

\begin{abstract}
:
Type 1 Diabetes Mellitus is an autoimmune disorder that occurs in the B-cells of pancreatic islets. Vitamin D is essential in maintaining the bone health. It has proven that Vitamin D has an autoimmune disorder including T1DM. Hence, the aim is to detect the prevalence of vitamin D deficiency among children with T1DM. A case control study conducted in Duhok, North of Iraq between $15^{\text {th }}$ of February and $15^{\text {th }}$ of August 2016. 100 enrolled participants aged from 5 to 15 years of both genders were divided in to two groups. Fifty of them had T1DM and 50 children who were healthy and non-diabetic. All participants were studied in terms of age, gender, duration of diabetes, glycemic control (HbAlc) and Body Mass index. Samples of blood were taken to measure serum Vitamin D and HbAlc levels. Mean serum Vitamin D level in diabetic group was $6.068 \pm 2.45 \mathrm{ng} / \mathrm{mL}$ while in the control group it was $21.101 \pm 9.23 \mathrm{ng} / \mathrm{mL}$. Vitamin $\mathrm{D}$ were lower in the diabetic patients than controls $(\mathrm{P}=0.01)$. Vitamin $\mathrm{D}$ level was indirectly correlated with duration of diabetes $(\mathrm{P}=0.01)$. Level of Vitamin $\mathrm{D}$ was decreased with increasing $\mathrm{HbA} 1 \mathrm{C}(\mathrm{P}=0.01)$. Level of Vitamin D was not significantly related to body mass index. Vitamin D level is not significantly related to body mass index.
\end{abstract}

KEYWORDS: Vitamin D, Diabetes Mellitus, Pediatric, Children, HbA1C

\section{INTRODUCTION}

Type 1 diabetes mellitus (T1DM) is an autoimmune disorder that occurs in the $\beta$-cells of the pancreatic islets (Bluestone, Herold, \& Eisenbarth, 2010). It represents $90 \%$ of diabetic cases in childhood and adolescence (Craig, Hattersley, \& Donaghue, 2009).The incidence of T1DM is significantly variable worldwide. Finland and Sardinia show the highest (Lammi et al., 2007), probably due to genetic, environmental and dietary factors that may play part in its pathogenesis (Forlenza \& Rewers, 2011).Vitamin D has a main effect in maintenance of bone health by regulating calcium in the body.

Vitamin D is obtained in two different ways. Its primary source comes from direct synthesis in skin (more than 90\%) through ultraviolet radiation exposure. The rest of need is obtained from dietary sources. After the process of hydroxylation that takes place in the liver it changes to D, 25hydroxy vitamin $\mathrm{D}(25[\mathrm{OH}]-\mathrm{D}$, calcidiol, or calcifediol) which are the storage forms of vitamin. Finally renal hydroxylation process of calcidiol leads to synthesis of the active metabolite, 1,25-dihydroxyvitamin D $(1,25[\mathrm{OH}]-\mathrm{D})$ (calcitriol) which is enhances absorption of calcium, resorption of bone, and decreases excretion of both phosphate and calcium through kidneys to maintain health of bone(Norman, 2008).

Moreover;vitamin D plays extra skeletal roles, with its receptors( vitamin D receptor (VDR), in different parts of body like colon, small intestine, lymphocytes, osteoblasts, , beta cells of pancreatic islet, and major organs including heart, brain, skin, gonads, prostate, breast, and mononuclear cells)(Adams \& Hewison, 2010). Regarding the high rate of development of bone in early life, sufficient concentrations of vitamin D in serum are mandatory for the growing child. There are evidences that vitamin $\mathrm{D}$ has a role in different autoimmune disorders including scleroderma, rheumatoid arthritis, , psoriasis, and also T1DM (Cutolo, Pizzorni, \&
Sulli, 2011). Vitamin D has strong immune modulatory and anti proliferative properties (Nagpal, Na, \& Rathnachalam, 2005).1,25(OH)2D3 plays an immune modulatory role in type 1 diabetes mellitus through activated $\mathrm{T}$ cells, antigen presenting cells and B -cells of islets of pancreas (Hewison, 2011). At the level of the pancreatic islets, vitamin D lowers expression of pro inflammatory chemokine and cytokine (e.g., IL6), which are involved in the pathogenesis of type 1DM rendering B -cells less chemo attractive and less liable to inflammation; this leads to decrease recruitment and infiltration of $\mathrm{T}$ cell, increasing regulatory cells, and arresting the autoimmune process (Gregori, Giarratana, Smiroldo, Uskokovic, \& Adorini, 2002).In addition, 1,25( $\mathrm{OH}) 2 \mathrm{D} 3$ lowers the expression of MHC class I leading to decreased vulnerability of B -cells of islets to cytotoxic T cells(R Riachy et al., 2001).

At the level of immune system, 1,25(OH)2D3 plays part in inhibition ofthe maturation of dendritic cells and potentiates their apoptosis (Emamaullee et al., 2009),thus preventing their transforming in to antigen presenting cells(Arnson, Amital, \& Shoenfeld, 2007).Also 1,25hydroxy vitamin D restores the suppressor cells, diminishes the Th1 cytokine production leading to the death of B -cell and directing the immune response toward Th2pathway leading to insulitis (Khoo et al., 2011). 1,25hydroxy vitamin D prevents the production of Il-6 which directlystimulatesTh17 cells(Emamaullee, et al., 2009),which play an important role in many autoimmune disorders, including type1 DM(Arnson, et al., 2007).On the other hand,1,25hydroxy vitamin D exerts an anti apoptotic effects on B -cells of pancreas. It helps producing high levels ofA20 gene protein, which reduces nitric oxide(Rita Riachy et al., 2002). And thereby down regulating all the mechanisms above and potentiating cyto protective effects on islet cells(R Riachy et al., 2006).

Considering the association between vitamin $\mathrm{D}$ and type $1 \mathrm{DM}$, many studies have found a significantly higher prevalence of vitamin $\mathrm{D}$ deficiency in T1DM patients in comparison with controls(Bener et al., 2009). while other studies found no significant difference(Chakhtoura \& Azar, 2013). 


\section{AIM OF THE STUDY}

The aim is to detect the prevalence of Vitamin D deficiency among diabetic children and whether there is any significant correlation between Vitamin D deficiency withT1DMin children.

\section{PATIENTS AND METHOD}

A case control study was conducted in Duhok, North of Iraq, between 15thofFebruary 2016 and 15thof August 2016.One hundred participants from both genders, aged5 to 15 years were studied. Fifty of them were Diabetic patients who were recorded in diabetic center in Duhok city, Kurdistan, Iraq. They had positive history of insulin dependent DM. Some had history of diabetic ketoacidosis. Some of them had good control on blood sugars and others were not depending on HbAlc. We excluded from the study any participant receiving multivitamins and Vitamin D supplementation therapy, or participants with any acute illness or obvious chronic disease. All participants were studied in terms of age, gender, duration of Diabetes, glycemic control (HbAlC) and the patients' growth as measured by Body Mass index.

Control group included 50 children who were apparently healthy, non diabetics and visited the hospital with their parents.

Before administration of any medication, venous blood samples were obtained under standard conditions for the measurement of serum Vitamin D levels and immediately sent to laboratory. Samples were centrifuged and serum samples were analyzed with atomic absorption spectrophotometry to measure serum Vitamin Dlevel. Serum Vitamin D status classified as follows(Allgrove \& Shaw, 2015):

- Deficient $(<10 \mathrm{ng} / \mathrm{mL})$

- Insufficient $(10-30 \mathrm{ng} / \mathrm{mL})$

- $\quad$ Sufficient $(>30 \mathrm{ng} / \mathrm{mL}$ )

Another blood sample was obtained from diabetic patients and was collected in EDTA tubes for the measurement of HbAlc. HbAlc status classified as follows(Association, 2003):

- Good control $(<7.9 \%)$

- $\quad$ Fair control $(8 \%$ to $9.9 \%)$

- Poor control $(\geq 10 \%)$

Ethical considerations: A written consent was taken from parents of patients and controls. The study was approved by Ethical Committee in Directorate of Health in Duhok.

Statistical analysis was performed by using the SPSS. Mean, standard deviation and $p$ values of two groups were obtained for comparison of serum Vitamin D levels between patients and controls and to assess the significance of the variables above in affecting serum Vitamin D level among patients.

\section{RESULTS}

Vitamin D was deficient in $45(90 \%)$ diabetic patients and in $6(12 \%)$ controls.

Lower levels of serum Vitamin D were detected in diabetic patients in comparison with control with a statistical significance difference $(\mathrm{P}$ value $=0.01)$, as shown in Table 1 and 2.
Table 1: Comparison between Serum Vitamin D levels in Diabetic and control group.

\begin{tabular}{|l|l|l|l|}
\hline Serum D3 levels & $\begin{array}{l}\text { Diabetic } \\
\text { patients }\end{array}$ & $\begin{array}{l}\text { Control } \\
\text { group }\end{array}$ & Total \\
\hline Deficient $(<10 \mathrm{ng} / \mathrm{mL})$ & $45(90 \%)$ & $6(12 \%)$ & $51(51 \%)$ \\
\hline $\begin{array}{l}\text { Insufficient }(10-30 \\
\text { ng/mL) }\end{array}$ & $5(10 \%)$ & $29(58 \%)$ & $34(34 \%)$ \\
\hline $\begin{array}{l}\text { Sufficient }(>30 \\
\text { ng/mL) }\end{array}$ & $0(0 \%)$ & $15(30 \%)$ & $15(15 \%)$ \\
\hline Total & $50(50 \%)$ & $50(50 \%)$ & $100(100 \%)$ \\
\hline
\end{tabular}

Table 2: Mean levels of serum Vitamin D in diabetic and control group.

\begin{tabular}{|l|l|l|l|}
\hline \multirow{2}{*}{ Groups } & \multirow{2}{*}{ No.(\%) } & $\begin{array}{l}\text { Serum D3 level } \\
(\mathrm{ng} / \mathrm{mL})\end{array}$ & \multirow{2}{*}{ P-value } \\
\cline { 3 - 4 } & & Mean $( \pm \mathrm{SD})$. & \\
\hline Diabetic patient & 50 & $6.068( \pm 2.45)$ & \\
\hline Controls & 50 & $21.101( \pm 9.23)$ & \multirow{2}{*}{0.01} \\
& & & \\
\hline
\end{tabular}

Male gender was predominant in both groups (54\% and 52\% respectively) and the most common age group among participants was $11-13$ years, representing $26 \%$ of the total population studied, as shown in Table 3.

Table 3: Age and gender distribution of both Diabetic patients and controls

\begin{tabular}{|c|c|c|c|c|c|c|}
\hline \multirow{2}{*}{$\begin{array}{c}\text { Age } \\
\text { (years) }\end{array}$} & \multicolumn{2}{|c|}{ Diabetic patients } & \multicolumn{3}{|c|}{ Control Group } \\
\cline { 2 - 7 } & $\begin{array}{c}\text { No.( } \\
\%)\end{array}$ & Male & $\begin{array}{c}\text { Fem } \\
\text { ale }\end{array}$ & No. & Male & Female \\
\hline $\begin{array}{c}5-<7 \\
\text { years }\end{array}$ & $\begin{array}{c}9(18 \\
\%)\end{array}$ & $\begin{array}{c}5(10 \\
\%)\end{array}$ & $\begin{array}{c}4(8 \% \\
)\end{array}$ & $\begin{array}{c}9(18 \\
\%)\end{array}$ & $\begin{array}{c}5(10 \\
\%)\end{array}$ & $4(8 \%)$ \\
\hline $\begin{array}{c}7- \\
<9 \text { years }\end{array}$ & $\begin{array}{c}10(20 \\
\%)\end{array}$ & $\begin{array}{c}5(10 \\
\%)\end{array}$ & $\begin{array}{c}5(10 \\
\%)\end{array}$ & $\begin{array}{c}10(2 \\
0 \%)\end{array}$ & $\begin{array}{c}5(10 \\
\%)\end{array}$ & $5(10 \%)$ \\
\hline $\begin{array}{c}9-<11 \\
\text { years }\end{array}$ & $\begin{array}{c}9(18 \\
\%)\end{array}$ & $\begin{array}{c}5(10 \\
\%)\end{array}$ & $\begin{array}{c}4(8 \% \\
)\end{array}$ & $\begin{array}{c}9(18 \\
\%)\end{array}$ & $\begin{array}{c}4(8 \% \\
)\end{array}$ & $5(10 \%)$ \\
\hline $\begin{array}{c}11-<13 \\
\text { years }\end{array}$ & $\begin{array}{c}13(26 \\
\%)\end{array}$ & $\begin{array}{c}7(14 \\
\%)\end{array}$ & $\begin{array}{c}6(12 \\
\%)\end{array}$ & $\begin{array}{c}13(2 \\
6 \%)\end{array}$ & $\begin{array}{c}7(14 \\
\%)\end{array}$ & $6(12 \%)$ \\
\hline $\begin{array}{c}13-15 \\
\text { years }\end{array}$ & $\begin{array}{c}9(18 \\
\%)\end{array}$ & $\begin{array}{c}5(10 \\
\%)\end{array}$ & $\begin{array}{c}4(8 \% \\
)\end{array}$ & $\begin{array}{c}9(18 \\
\%)\end{array}$ & $\begin{array}{c}5(10 \\
\%)\end{array}$ & $4(8 \%)$ \\
\hline Total & $\begin{array}{c}50(10 \\
0 \%)\end{array}$ & $\begin{array}{c}27(5 \\
4 \%)\end{array}$ & $\begin{array}{c}23(4 \\
6 \%)\end{array}$ & $\begin{array}{c}50(1 \\
0 \%\end{array}$ & $\begin{array}{c}26(52 \\
\%)\end{array}$ & $24(48 \%)$ \\
\hline
\end{tabular}

Serum Vitamin D level decreases with increased duration of diabetes and this is statistically significant as shown in Table 4 
Table 4: Relation between mean Serum Vitamin Dlevels \& duration of diabetes.

\begin{tabular}{|l|l|l|l|}
\hline $\begin{array}{l}\text { Duration of } \\
\text { D.M }\end{array}$ & No. & Serum D3 level $(\mathrm{ng} / \mathrm{mL})$ & \multirow{2}{*}{ P-value } \\
\cline { 3 - 3 }$<1$ year & 10 & $8.96( \pm 2.91)$ & \\
\cline { 1 - 2 } $1-5$ years & 33 & $5.57( \pm 1.78)$ & \multirow{2}{*}{0.01} \\
\cline { 1 - 2 }$>5$ years & 7 & $4.24( \pm 0.45)$ & \\
\hline Total & 50 & $6.06( \pm 2.45)$ & \\
\hline
\end{tabular}

As shown in Table 5, Serum Vitamin D level significantly decreases with increasingHbA1c level, which indicates poor glycemic control $(\mathrm{P}=0.01)$.

Table 5: Comparison between mean Serum D3 levels \& glycemic control (HBA1C)

\begin{tabular}{|l|l|l|l|}
\hline $\begin{array}{l}\text { Glycemic } \\
\text { control (HBA1C } \\
\%)\end{array}$ & No. & $\begin{array}{l}\text { Serum D3 level( } \\
\text { ng/mL) }\end{array}$ & P-value \\
\cline { 2 - 3 } $\begin{array}{l}\text { Good control } \\
<7.9 \%\end{array}$ & 16 & Mean $( \pm$ SD. $)$ & \\
\hline $\begin{array}{l}\text { Fair control } \\
8 \% \text { to } 9.9 \%\end{array}$ & 15 & $6.14( \pm 2.67)$ & \multirow{2}{*}{0.01} \\
\hline $\begin{array}{l}\text { Poor control } \\
\geq 10 \%\end{array}$ & 19 & $4.69( \pm 1.04)$ & \\
\hline Total & 50 & $6.06( \pm 2.45)$ & \\
\hline
\end{tabular}

Serum Vitamin D level was not found to be significantly related to body mass index in diabetic patients although the overweight and obese patients had the lowest level as shown in Table 6 .

Table 6: comparison between BMI of diabetics \& mean of Serum D3.

\begin{tabular}{|l|l|l|l|}
\hline \multicolumn{1}{|c|}{ BMI } & No. & $\begin{array}{l}\text { Serum D3 } \\
\text { level(ng/mL })\end{array}$ & \multirow{2}{*}{ P-value } \\
\cline { 3 - 3 } & Mean $( \pm$ SD. $)$ & \\
\hline $\begin{array}{l}\text { Under } \\
\text { weight } \\
<5 \%\end{array}$ & 6 & $8.04( \pm 3.46)$ & \\
\hline $\begin{array}{l}\text { Normal } \\
5 \% \text { to } 85 \%\end{array}$ & 38 & $5.92( \pm 2.25)$ & \\
\hline $\begin{array}{l}\text { Overweight } \\
85 \% \text { to } 95 \%\end{array}$ & 5 & $5.21( \pm 1.92)$ & \multirow{2}{*}{0.14} \\
\hline $\begin{array}{l}\text { Obese } \\
>95 \%\end{array}$ & 1 & 4.00 & \\
\hline \multirow{2}{*}{ Total } & 50 & $6.06( \pm 2.45)$ & \\
\hline
\end{tabular}

\section{THE DISCUSSION}

The current study found that Vitamin D level was significantly lower in T1DMchildren as compared to the control group. The mean serum Vitamin D level was 6.068 $\pm 2.45 \mathrm{ng} / \mathrm{mL}$ in diabetic group while in the control group was
$21.101 \pm 9.23 \mathrm{ng} / \mathrm{mL}$. Low serum Vitamin D level in this study was present in $90 \%$ of the participants.

It was found by many studies that prevalence of Vitamin D deficiency is higher in T1 DM patients in comparison to controls(Bener, et al., 2009; Borkar, Devidayal, Verma, \& Bhalla, 2010; Greer et al., 2013; Hamed, Abu Faddan, Adb Elhafeez, \& Sayed, 2011; Pozzilli et al., 2005).

However; a study accomplished in the United States found no significant difference in levels of serum Vitamin D between T1DM patients and controls(Bierschenk et al., 2009).

It is clearly shown in this study that serum Vitamin D level is inversely correlated with $\mathrm{HbAlc}$. This is in agreement with other studies(Elsayed \& Mohamed, 2016; Wulandari, Cahyono, Widjajanto, \& Puryatni, 2014)which found a significant difference in HbAlc levels in type 1diabetic children in comparison with the controls, and also stated that $\mathrm{HbAlc}$ levels are negatively correlated with the vitamin D levels in T1DM. Moreover, another study found that vitamin D3 replacement produces a better glycemic control in patients with T1DM and improves HbA1C level in different glycemic control groups; good, fair, and poor(Mohammadian, Fatahi, Zaeri, \& Vakili, 2015).In contrary, two other studies found no such correlation(El Baba, Zantout, Akel, \& Azar, 2011; Tunc, Cetinkaya, \& Kizilgun, 2010).

Although the reason behind Vitamin D deficiency in T1 DM patients was not well understood, several mechanisms explain vitamin D deficiency relation with poor glycemic control. First, patients who were included in the study spent most of the time indoors, with poor outdoor activities and exercise especially in hot summer. Secondly, Vitamin D helps improving sensitivity to insulin in insulin-responsive tissues, like fat tissue and skeletal muscle, through stimulation of the expressing insulin receptors and/or by activation of peroxisome proliferator-activated receptor- $\delta$. Calcium plays an important role in intracellular processes mediated by insulin. Vitamin D exerts its indirect effect by regulation of movement of calcium across the cell membrane and maintaining intracellular calcium(Harinarayan, 2014).

Third, loss of vitamin D binding protein in urine is caused by poor efficacy and or reduce amount of megalin or low-density lipoprotein related protein 2 correlated with proteinuria. In proximal tubule, Megalin acts as a receptor to albumin, enzymes, hormones, lipoproteins, vitamin-binding protein and drugs. It helps in generating 1,25hydroxy vitamin D following the re absorption of the binding protein-25OHvitamin D complex by megalin endocytic receptor(Thrailkill, Jo, Cockrell, Moreau, \& Fowlkes, 2011) .

In addition, allelic variations of VDR is linked to deficiency of vitamin D in T1DM patients has been shown by retrospective observational studies(Janner, Ballinari, Mullis, \& Flück, 2010). In this study, serum Vitamin D level is inversely correlated with the duration of diabetes. This is in contrast to Tunisian and USA study that found no significant difference between vitamin $\mathrm{D}$ and duration of diabetes(Sonia et al., 2016; Thrailkill, et al., 2011). This may be indicative of multifactorial cause of Vitamin D deficiency in T1DM.

Lastly, the current study shows that there was no significant correlation between body mass index and serum Vitamin D level, which is in accordance with other studies(Dutta et al., 2013; Sonia, et al., 2016)thus precluding any direct effect of nutritional status on the status of body Vitamin D.

\section{CONCLUSION}

Serum Vitamin D level is significantly lowers in diabetic children as compared to the control group. Serum Vitamin D level is inversely correlated with the duration of the disease. Serum Vitamin D is inversely related to HbAlc level. No significant correlation was found between serum Vitamin D level and body mass index. 


\section{RECOMMENDATIONS}

Vitamin D supplementation might be considered a useful additional intervention for improving outcome in patients with Insulin dependent DM. A large follow up study is recommended to look on the effect of Vitamin D supplementation in patients with T1DM.Further extended cohort study is indicated to look on the relations between the Insulin dependent DM patients and serum Vitamin D level.

\section{REFERENCES}

Adams, J. S., \& Hewison, M. (2010). Update in vitamin D. The Journal of Clinical Endocrinology \& Metabolism, 95(2), 471-478.

Allgrove, J., \& Shaw, N. J. (2015). A practical approach to vitamin $\mathrm{D}$ deficiency and rickets Calcium and Bone Disorders in Children and Adolescents (Vol. 28, pp. 119-133): Karger Publishers.

Arnson, Y., Amital, H., \& Shoenfeld, Y. (2007). Vitamin D and autoimmunity: new aetiological and therapeutic considerations. Annals of the rheumatic diseases, 66(9), 1137-1142.

Association, A. D. (2003). Standards of medical care for patients with diabetes mellitus. Diabetes Care, 26(suppl 1), s33s50.

Bener, A., Alsaied, A., Al-Ali, M., Al-Kubaisi, A., Basha, B., Abraham, A., et al. (2009). High prevalence of vitamin D deficiency in type 1 diabetes mellitus and healthy children. Acta diabetologica, 46(3), 183.

Bierschenk, L., Alexander, J., Wasserfall, C., Haller, M., Schatz, D., \& Atkinson, M. (2009). Vitamin D levels in subjects with and without type 1 diabetes residing in a solar rich environment. Diabetes Care, 32(11), 1977-1979.

Bluestone, J. A., Herold, K., \& Eisenbarth, G. (2010). Genetics, pathogenesis and clinical interventions in type 1 diabetes. Nature, 464(7293), 1293.

Borkar, V. V., Devidayal, Verma, S., \& Bhalla, A. (2010). Low levels of vitamin D in North Indian children with newly diagnosed type 1 diabetes. Pediatric diabetes, 11(5), 345350 .

Chakhtoura, M., \& Azar, S. T. (2013). The role of vitamin d deficiency in the incidence, progression, and complications of type 1 diabetes mellitus. International Journal of Endocrinology, 2013.

Craig, M. E., Hattersley, A., \& Donaghue, K. C. (2009). Definition, epidemiology and classification of diabetes in children and adolescents. Pediatric diabetes, 10, 3-12.

Cutolo, M., Pizzorni, C., \& Sulli, A. (2011). Vitamin D endocrine system involvement in autoimmune rheumatic diseases. Autoimmunity reviews, 11(2), 84-87.

Dutta, D., Maisnam, I., Shrivastava, A., Sinha, A., Ghosh, S. Mukhopadhyay, P., et al. (2013). Serum vitamin-D predicts insulin resistance in individuals with prediabetes. The Indian journal of medical research, 138(6), 853.

El Baba, K., Zantout, M. S., Akel, R., \& Azar, S. T. (2011). Seasonal variation of vitamin $\mathrm{D}$ and $\mathrm{HbA} 1 \mathrm{c}$ levels in patients with type 1 diabetes mellitus in the Middle East. International journal of general medicine, 4, 635 .

Elsayed, A. M., \& Mohamed, G. A. (2016). Vitamin D deficiency and its correlation to hemoglobin $\mathrm{A} 1 \mathrm{C}$ in adolescent and young adult type 1 diabetes mellitus patients. Al-Azhar Assiut Medical Journal, 14(2), 76

Emamaullee, J. A., Davis, J., Merani, S., Toso, C., Elliott, J. F., Thiesen, A., et al. (2009). Inhibition of Th17 cells regulates autoimmune diabetes in NOD mice. Diabetes.

Forlenza, G. P., \& Rewers, M. (2011). The epidemic of type 1 diabetes: what is it telling us? Current Opinion in Endocrinology, Diabetes and Obesity, 18(4), 248-251.

Greer, R. M., Portelli, S. L., Hung, B. S. M., Cleghorn, G. J., McMahon, S. K., Batch, J. A., et al. (2013). Serum vitamin D levels are lower in Australian children and adolescents with type 1 diabetes than in children without diabetes. Pediatric diabetes, 14(1), 31-41.

Gregori, S., Giarratana, N., Smiroldo, S., Uskokovic, M., \& Adorini, L. (2002). A 1 $\alpha, 25$-dihydroxyvitamin D3 analog enhances regulatory $\mathrm{T}$-cells and arrests autoimmune diabetes in NOD mice. Diabetes, 51(5), 1367-1374.

Hamed, E. A., Abu Faddan, N. H., Adb Elhafeez, H. A., \& Sayed, D. (2011). Parathormone-25 (OH)-vitamin D axis and bone status in children and adolescents with type 1 diabetes mellitus. Pediatric diabetes, 12(6), 536-546.

Harinarayan, C. V. (2014). Vitamin D and diabetes mellitus. Hormones, 13(2), 163-181.

Hewison, M. (2011). Vitamin D and innate and adaptive immunity Vitamins \& hormones (Vol. 86, pp. 23-62): Elsevier.

Janner, M., Ballinari, P., Mullis, P.-E., \& Flück, C. (2010). High prevalence of vitamin D deficiency in children and adolescents with type 1 diabetes. Swiss medical weekly, 140, w13091.

Khoo, A. L., Joosten, I., Michels, M., Woestenenk, R., Preijers, F., He, X. H., et al. (2011). 1, 25-Dihydroxyvitamin D3 inhibits proliferation but not the suppressive function of regulatory $\mathrm{T}$ cells in the absence of antigen-presenting cells. Immunology, 134(4), 459-468.

Lammi, N., Taskinen, O., Moltchanova, E., Notkola, I., Eriksson, J., Tuomilehto, J., et al. (2007). A high incidence of type 1 diabetes and an alarming increase in the incidence of type 2 diabetes among young adults in Finland between 1992 and 1996. Diabetologia, 50(7), 1393-1400.

Mohammadian, S., Fatahi, N., Zaeri, H., \& Vakili, M. A. (2015). Effect of vitamin $\mathrm{d} 3$ supplement in glycemic control of pediatrics with type 1 diabetes mellitus and vitamin d deficiency. Journal of clinical and diagnostic research: JCDR, 9(3), SC05.

Nagpal, S., Na, S., \& Rathnachalam, R. (2005). Noncalcemic actions of vitamin D receptor ligands. Endocrine reviews, 26(5), 662 687

Norman, A. W. (2008). From vitamin D to hormone D: fundamentals of the vitamin D endocrine system essential for good health-. The American journal of clinical nutrition, 88(2), 491S-499S

Pozzilli, P., Manfrini, S., Crinò, A., Picardi, A., Leomanni, C., Cherubini, V., et al. (2005). Low levels of 25-hydroxyvitamin D3 and 1, 25-dihydroxyvitamin D3 in patients with newly diagnosed type 1 diabetes. Hormone and Metabolic Research, 37(11), 680-683

Riachy, R., Vandewalle, B., Belaich, S., Kerr-Conte, J., Gmyr, V., Zerimech, F., et al. (2001). Beneficial effect of 1,25 dihydroxyvitamin D3 on cytokine-treated human pancreatic islets. Journal of endocrinology, 169(1), 161-168.

Riachy, R., Vandewalle, B., Kerr Conte, J., Moerman, E., Sacchetti, P., Lukowiak, B., et al. (2002). 1, 25-dihydroxyvitamin D3 protects RINm5F and human islet cells against cytokineinduced apoptosis: implication of the antiapoptotic protein A20. Endocrinology, 143(12), 4809-4819.

Riachy, R., Vandewalle, B., Moerman, E., Belaich, S., Lukowiak, B., Gmyr, V., et al. (2006). 1, 25-Dihydroxyvitamin D3 protects human pancreatic islets against cytokine-induced apoptosis via down-regulation of the Fas receptor. Apoptosis, 11(2), 151-159.

Sonia, H.-L., Ali, M., Yousr, D., Wiem, B., Anies, H., Kamel, H., et al. (2016). Serum Vitamin D Level in Children with and without Type 1 Diabetes Mellitus. J Diabetes Metab, 7(655), 2.

Thrailkill, K. M., Jo, C.-H., Cockrell, G. E., Moreau, C. S., \& Fowlkes, J. L. (2011). Enhanced excretion of vitamin D binding protein in type 1 diabetes: a role in vitamin D deficiency? The Journal of Clinical Endocrinology \& Metabolism, 96(1), 142-149.

Tunc, O., Cetinkaya, S., \& Kizilgun, M. (2010). Evaluation of the relation between vitamin $\mathrm{D}$ and insulin requirements and frequency of osteopenia/osteoporosis in childhood with type 1 diabetes. Paper presented at the 49th Annual Meeting of the ESPE September.

Wulandari, D., Cahyono, H. A., Widjajanto, E., \& Puryatni, A. (2014). Low levels of vitamin D correlate with hemoglobin A1c and interleukin-10 levels in pediatric type 1 diabetes mellitus patients. Journal of Tropical Life Science, 4(3), 182-186. 